\title{
Keynes and the European economy
}

\author{
Peter Temin* \\ Massachusetts Institute of Technology, Cambridge, MA, USA \\ David Vines* \\ Balliol College, University of Oxford, UK
}

We argue in this paper that Keynes was interested primarily in the world economy. We do not seek to diminish the innovative advances Keynes made in The General Theory; we instead want to expand the perceived scope of Keynesian economics. We make this argument by analysing Keynes's contributions at three points during his career: writing The Economic Consequences of the Peace just after the First World War, testifying before the Macmillan Committee at the outset of the Great Depression, and negotiating at Bretton Woods during and after the Second World War. We then show how international Keynesian analysis clarifies the economic problems of Europe today.

Keywords: Keynes, international, The Economic Consequences of the Peace, Macmillan Committee, Bretton Woods

JEL codes: $B 22, F 41, N 14$

\section{INTRODUCTION}

We argue in this paper that Keynes was interested primarily in the world economy. He wrote The General Theory (1936) as a necessary part of this grand design, and then he died prematurely just after the Second World War. The success of The General Theory overshadowed Keynes's research design, and he is best known today as an analyst of a closed economy. To expand Keynesian analysis to the world economy, we survey Keynes's thought process through his active career and use his framework to analyse current European conditions.

\section{KEYNES'S RESEARCH PROGRAM: THEORIZING THE GLOBAL ECONOMY}

Keynes wrote The Economic Consequences of the Peace (1919) to protest against what had happened at Versailles. He prefaced his analysis of the Versailles negotiations and treaty with a description of economic conditions before the Great War in order to set up a contrast with the dismal postwar conditions he described later. He opened his

* Peter Temin is Elisha Gray II Professor Emeritus of Economics at MIT and the author of Lessons from the Great Depression and other books. David Vines is Professor of Economics and Fellow of Balliol College at the University of Oxford, and joint editor of a number of books on global economic governance. Temin and Vines are coauthors of The Leaderless Economy: Why the World Economic System Fell Apart and How to Fix It. 
discussion with a paragraph that has been quoted widely ever since, starting with the claim that:

The inhabitant of London could order by telephone, sipping his morning tea in bed, the various products of the whole earth, in such quantity as he might see fit, and reasonably expect their early delivery upon his doorstep; he could at the same moment and by the same means adventure his wealth in the natural resources and new enterprises of any quarter of the world, and share, without exertion or even trouble, in their prospective fruits and advantages; or he could decide to couple the security of his fortunes with the good faith of the townspeople of any substantial municipality in any continent that fancy or information might recommend. (Keynes 1919, beginning of ch. 2)

In this paean to prewar prosperity, Keynes revealed his interests in the world economy and the long run. Britain had had a century of industrial leadership that made it the 'workshop of the world' by the mid nineteenth century, and the Crystal Palace Exhibition that marked this status was held in a building that was as much the result of new technologies as the exhibits it contained.

In a remarkable few pages in The Economic Consequences of the Peace, Keynes set out to explain how this process of growth had worked for Europe as a whole. Technological development, rapid population growth, and the movement of people out of agriculture and into cities had made it possible for the industrial output of Britain, and later Germany, to grow at an unprecedented rate. In addition, as Keynes observed, wages remained low and profits were high. These high profits enabled a very rapid accumulation of capital in both Britain and then in Germany. Crucially, this was an international system.

First Britain exported its technology and its products around the world, and it emerged as the world's financial center in the process. When other countries could not pay for railroads or even cotton goods on their own, the British were happy to lend them money to do so. By the beginning of the twentieth century, British consumers enjoyed themselves as Keynes described both from sales of new goods and earnings from the bonds they had bought from abroad.

Then in the last quarter of the nineteenth century, Germany followed the British pattern, as Keynes described:

On the prosperity and enterprise of Germany, the prosperity of the rest of the Continent mainly depended. The increasing pace of Germany gave her neighbors an outlet for their products, in exchange for which the enterprise of the German merchant supplied them with their chief requirements at a low price. ... Germany not only furnished these countries with trade, but, in the case of some of them, supplied a great part of the capital needed for their own development. (Ibid.)

Like Britain before it, Germany exported its products even to countries that could not pay for them up front. It loaned other countries money to invest in German products as Britain had done before to expand its markets. This was a world system in the sense that it extended throughout Europe and America, although it only penetrated isolated countries outside the industrial center. Production was needed for prosperity, as was the willingness of investors in Britain and Germany to forego consumption from their earnings to invest in the prospects that other countries would grow in response to their contacts with the industrial leaders. We call the policies of Germany in that period - and of Britain before it - export-led growth. Any reader today will recognize this pattern a century later as a prominent feature of the eurozone in which German exports drove prosperity in the first decade of the twenty-first century. 
Early in his career, Keynes set out this theory of economic growth, describing a process that also was at work in Europe after the Second World War. Growth starts when technical progress in one country leads to an expansion of productive capacity there. But living standards do not increase as soon or as fast as production. New business firms have to search abroad for additional markets, giving rise to export-led growth. Keynes described this in England and Germany a hundred years ago; we have seen it more recently again in Europe.

Keynes clearly saw the prewar prosperity as the result of the workings of a world economy. He is celebrated today primarily for his contributions to the analysis of what is known as a closed economy, that is, an economy without foreign trade or investments. This description indicates clearly that Keynes knew that domestic prosperity was critically determined by external conditions. As he emphasized throughout The Economic Consequences of the Peace, the former is unattainable without the latter.

Ten years later, Keynes did not fully understand his own story. In particular he did not yet know how to respond when domestic prosperity was threatened by bad developments abroad. As we shall see, he struggled to articulate a view about this in 1930 in front of the Macmillan Committee. That failure led him to write his General Theory, in order to understand the widespread unemployment which emerges when the economy is not well managed - and it led him to propose a 'Keynesian' solution to this problem. Again in the early 1940s Keynes struggled to understand how to extend his Keynesian solution to the world economy; he could not yet see how to manage the processes of international adjustment that would eventually arise. That failure led him to work towards the establishment of an international monetary system that was established at Bretton Woods with the creation of the International Monetary Fund. We argue in this paper that the primary aim of Keynes's whole professional career was the establishment of the process of international adjustment that is embodied in the International Monetary Fund.

In his Economic Consequences of the Peace, Keynes went on to condemn the reparations imposed on Germany at Versailles as economically irrational and politically unwise. He immediately achieved worldwide fame as a result of the stand that he took on this issue. He argued that reparations functioned like German debts. They therefore would reverse the flow of capital from Germany before the war. Germany would go from being a cheerful creditor of other nations to a reluctant and recalcitrant borrower. The preceding period of prosperity would be thrown into confusion by this reversal of economic relations between European countries.

Keynes concluded his discussion of the treaty with a strong statement of his opinion:

The policy of reducing Germany to servitude for a generation, of degrading the lives of millions of human beings, and of depriving a whole nation of happiness should be abhorrent and detestable - abhorrent and detestable, even if it were possible, even if it enriched ourselves, even if [it] did not sow the decay of the whole civilised life of Europe. (Keynes 1919, end of ch. 5)

He predicted continued hostility and opposition to the treaty and reparations. He did not foresee any cooperative movements by any of the previous combatants:

All these influences ... favor a continuation of the present conditions instead of a recovery from them. An inefficient, unemployed, disorganized Europe faces us, torn by internal strife and international hate, fighting, starving, pillaging, and lying. What warrant is there for a picture of less somber colors? (Ibid., end of ch. 6) 
Economic conditions in the 1920s were even more depressing than Keynes had predicted in The Economic Consequences. The first half of the decade was replete with hyperinflations and bank crises that crisscrossed Europe. Germany resisted paying reparations - the 'debt' they had inherited from the war and the Versailles Treaty. The French and Belgians invaded Germany's coal and steel areas to force the Germans to pay up. The Germans responded by inflating their currency to reduce their debt, resulting in a famous hyperinflation. At the same time, Britain was deflating to return to gold at the old rate, generating internal strife as the government strove mightily to reduce wages and ending in a General Strike.

This turbulent period was brought to an end by a massive loan from the United States to Germany in 1924 that enabled the Germans to end their hyperinflation and regain the appearance of normality. The rest of the decade appeared to be prosperous in each country by itself, but the poisonous presence of international obligations indicated that this economic edifice was built on sand. The American loan did not eliminate the international flows of capital from war loans and reparations, and it did not eliminate the German resentment of reparations - the national debt Germany had incurred by the war and at Versailles.

Prosperity faltered at the end of the 1920s as first Germany and then the United States went into recession. The causes of these recessions are neither clear nor important; they both came from imbalances that had led to unsustainable booms in German municipal spending and in the New York stock market. Recession in the two main industrial countries led through misguided economic policies to distress throughout Europe and the wider world.

Britain's economic position at the end of the 1920s was particularly dire. The country had returned to the gold standard at an uncompetitive exchange rate in 1925, and the British economy had been radically weakened by the First World War. Its holdings of overseas assets had been significantly run down to pay for the war, thus curtailing Britain's income from abroad. At the same time, Britain remained the only possible leader of the world.

A new Labour government came to power in 1929, and policymaking was overwhelmed by the Wall Street Crash. The Prime Minister therefore created a committee of enquiry, which became known as the Macmillan Committee after its chairman, a Scottish judge. The committee was not required to advise on any particular economic policy question; it was instead to carry out a wide-ranging investigation of the options facing both Britain and the world. The Macmillan Committee is remembered today because it provides a clear window into Keynes's thought processes in 1930.

Keynes's preparation for the committee went back to The Economic Consequences of the Peace. In addition, Keynes had been working on a restatement of monetary theory for the previous five years, and the resulting Treatise on Money was in the process of publication as the committee convened for its meetings. The Treatise was written in the late 1920s when the world was prosperous. It therefore extended Marshall's tradition of analysing fully employed economies, in which the macroeconomic framework was provided by the Quantity Theory of Money.

Prices were assumed to be flexible in this framework, and they could move to equilibrate all markets. As Britain's primary problem in 1930 was unemployment, however, Marshall's framework did not help Keynes as much as he hoped. In fact, the Macmillan Committee is of interest to us because his presentations to the committee did not add up to a coherent view. It reveals Keynes thinking on his feet at a time when his ideas were in flux. 
It was obvious to Keynes that his testimony did not add up, and his inability to attract any of the other members of the committee to his views set the stage for the work he was to carry out for the next fifteen years. It led him to focus on two great questions in the final fifteen years of his life. How is extensive and continuing unemployment caused, and how can it be alleviated? And how can countries at different levels of income and in different states of economic development interact with each other in economic harmony? His answers to these questions enabled him to turn the vision of his age which he expounded in The Economic Consequences of the Peace into a system for managing the world economy.

Keynes signaled his international orientation by beginning his presentation to the Macmillan Committee with an introduction on the gold standard. He started his analysis of the domestic economy by describing external adjustments:

I have decided that probably the best way will be to begin rather in the middle and then work forwards and backwards, starting from the things that are probably relatively familiar and keeping till the last some of the things which I hold of great importance, but which are likely to be less familiar. I think it will be useful if, first of all, we go through the more or less orthodox theory of how Bank rate works, the classical theory of Bank rate as it has existed in this country for the last 50 years.

So long as we are on the gold standard, the fundamental principle of our currency management has to be that the differences between our international receipts and payments which we have to meet or receive in gold shall never be very large. We cannot afford to use lose large quantities of gold, or at any rate to lose them continuously. So ... the primary task of currency management is to keep an approximate equality between our international receipts and payments. This balance is made up of two parts. (Keynes 1981, p. 39)

The first, short-term, component of the expanded gold-standard mechanism worked as follows. If a country was exporting less than it imported, then it would be the task of its monetary authority to raise the interest rate in order to attract funds from abroad and cover the cost of imports. This action could cushion the deficit which a country was experiencing, ensuring that it attracted enough gold for it to use to pay for its imports. The Bank of England was at the center of this international financial system, and it had much experience of adjusting Bank rate in this way.

But, Keynes claimed, such short-term cushioning could not solve the underlying external difficulty facing an economy like that of Britain. He described a second, longer-term, component of the gold standard mechanism. This required that the interest rate be held at a high level sufficiently long to cause a fall in investment and induce a fall in the overall demand for domestic goods. This in turn would lead to in an increase in the unemployment of labor, which would cause wages to fall. Unemployment had to remain high for a sufficiently long period and wages had to fall by a sufficiently large amount for the economy to become competitive again.

The economy then would be able to gain export markets again, and it would export enough to pay for its imports. It would no longer need high interest rates to attract funds from abroad. There is, said Keynes, no other way by which Bank rate brings down prices, except by increasing unemployment. That, he concluded, 'is the beginning and end of traditional sound finance in this country' (ibid.).

This may not sound like a radical innovation to a modern audience, but it was new in 1930. Marshall had used the Quantity Theory of Money to show how the level of prices in the economy is determined by the quantity of money in existence. This idea had become a central idea in economics teaching, for it was a necessary part of any attempt to connect monetary phenomena (about prices) with real phenomena (about 
how many actual goods and services are bought and sold in an economy) in the absence of what we now call Keynesian macroeconomics. Keynes now separated the workings of the gold-standard mechanism into two components: a short-term effect on capital inflows, operating as a result of a rise in Bank rate, and a longer-term effect, operating through an improvement in competitiveness which was caused by unemployment and which was, in turn, caused by the increase in Bank rate. This seems rather trite to us, but it was a dramatic change of view for an audience in 1930.

Keynes expressed an important doubt whether the second, longer-term component of the adjustment process could be made to work adequately, except when wages were growing and adjustment required only that wages grow less rapidly. Keynes maintained that that was why the gold standard had worked satisfactorily in the late nineteenth century. By contrast Keynes denied that money wages had ever been downwardly flexible in the way which was now required.

My reading of history is that for centuries there has existed an intense social resistance to any matters of reduction in the level of money incomes. I believe that, apart from the adjustments due to cyclical fluctuations, there has never been in modern or ancient history any community that has been prepared to accept without immense struggle a reduction in the general level of money income. ... The ... deflation which followed the Napoleonic Wars, ... very much like the one we are going through now, was one which brought the country to the verge of revolution ... (Ibid., p. 76)

These problems of wage adjustment explained why problems had emerged since Britain rejoined the gold standard in 1925 at an overvalued exchange rate. Keynes thought that this policy decision had led to the miners' strike and then the General Strike of 1926, to the collapse of the Lancashire cotton industry in the years that followed, and to the unemployment that was widespread in Britain by 1930. It also explained why the economic policies of the immediately succeeding years were both misguided and dysfunctional. Austerity, as we now call it, did not lead to external balance in the early 1930s, and it does not work in Southern Europe today.

\section{THE GENERAL THEORY AS PRELUDE TO A THEORY OF THE GLOBAL ECONOMY}

Keynes realized he had to answer the first question about unemployment before he could turn to the problems of international adjustment. That led him to the work that produced The General Theory. This dramatic book revolutionized our understanding of the domestic economy and is justifiably famous. It was such a dramatic change in our understanding that we now speak of Keynesian unemployment.

The General Theory also was a necessary foundation for the work which Keynes went on to do on international issues. We therefore need to understand the way in which The General Theory was necessary for that work. Only then can we appreciate the magnitude of what Keynes achieved when he returned to international issues.

We use simple supply and demand curves to see how Marshall and his followers would have analysed the problem that Keynes was grappling with during his presentations to the Macmillan Committee. To someone like Keynes, trained in the Marshallian tradition, the problem of unemployment is caused by trade unions and other institutions keeping the wage above the market clearing level. At that level, the price for labor (that is, the wage) is above the equilibrium level. The amount of labor that workers would like to supply is larger than the amount of labor that business firms are 
willing to hire. More formally, the supply of labor exceeds the demand for labor at this high wage.

If wages were cut, this would increase the demand for labor because business firms would find it profitable to hire more workers. A wage cut also would reduce the supply of labor, as some workers would find it less desirable to find a job at the lower wage. This is how to understand Montagu Norman, the Governor of the Bank of England, who opposed Keynes at the Macmillan Committee. According to Norman, the Bank of England had no effect on employment. He said that employment was determined by the wages set within each industry, which had nothing to go with Bank of England policy. Wage adjustment was, he said, a matter for industry, and for its workers: 'I have never been able to see myself why for the last few years it should have been impossible for industry, starting from within, to have readjusted its own position' (Norman 1931, p. 3339).

Only after Keynes had written The General Theory could he see how to object to such an analysis. According to The General Theory, if wages were cut but there was no increase in aggregate demand at the same time, then firms would find themselves unable to sell any increase in output, and so would not increase their demand for labor. A cut in wages would simply lead firms to cut their prices.

The problem of an imbalance between savings and investment was analysed similarly in the Marshallian tradition. The price for savings and investment was taken to be the interest rate in that tradition. At a high interest rate, people are eager to save, and the supply of savings slopes upward. The demand for investment by business firms would be low at a high interest rate because the firm would have to pay more to borrow funds to invest. The interest rate would move to equilibrate them. Parallel to the analysis of the labor market, an interest rate above the equilibrium level would produce an excess supply of savings relative to the demand for investment. A decrease in the interest rate would lead to an equilibrium where the supply of savings equals the demand for investment. In this Marshallian framework, there is no reason to ever think that an excess supply of savings could lead to a reduction in production, as Keynes wanted to argue.

It was also only after Keynes had written The General Theory that he saw how to object to such analysis. According to The General Theory, if people decided to save more there would not be any reduction in the interest rate - or at least there would not be much of a reduction - as The General Theory argued that the interest rate was determined in the money market. The interest rate - said The General Theory - would adjust to make the demand for money equal to the supply of money, rather than adjusting to make savings equal to investment. And so when savings increased there would emerge a 'Paradox of Thrift.' Savings would be brought into line with investment, not by a fall in the interest rate, but by a fall in output.

This was the kind of analysis which Keynes tried to deploy at the Macmillan Committee. Keynes wanted to argue there that if a country was exporting less than it imported, then it would be the task of the monetary authority to raise the interest rate, in order to attract funds from abroad and cover the cost of imports, to prevent gold from flowing out and the supply of money from falling. He wanted to argue that keeping the interest rate high in this way would cause a reduction in investment and lead to a fall in the overall demand for domestic goods, and so would lead to unemployment. That would cause wages to fall, and it was this fall in wages which was meant to enable the economy to become competitive again. That, he concluded, is how sound finance was meant to work. There is, he said, no other way by which adjustment could happen in an uncompetitive economy, except by reducing output and increasing unemployment. 
But such a line of argument was unobtainable for Keynes at the time of the Macmillan Committee. This is because he still believed that the interest rate would adjust to ensure that investment and savings were equalized, and resources would remain fully employed.

Indeed the very possibility of low output of goods and of generalized unemployment that Keynes was trying to understand seemed completely impossible to comprehend for people trained in the Marshallian tradition. The Quantity Theory of Money told them that prices would adjust to make sure that low output could not emerge. With a fixed quantity of money, prices were set by the demand for money. The lower the price of goods, the greater the quantity of goods that would be demanded; prices would settle at the level at which the quantity of money was just enough to enable all of the goods produced in the economy to be purchased. Of course, prices needed to be flexible to enable this to happen.

Keynes had not yet seen why this did not happen. Only by writing The General Theory did he come to understand this part of his own argument. Only then did he understand that, because wages only adjust gradually in the presence of unemployment, the kind of price flexibility on which Marshall had relied would not be able to ensure that everything produced would actually be purchased. It is easy now to see the connection between, on the one hand, Keynes's unconvincing analysis at the Macmillan Committee of why the gold standard did not work and, on the other hand, the macroeconomic system which he developed in The General Theory. The fact that wages only adjust gradually in the presence of unemployment is what, he had argued, makes the gold standard unworkable. This same fact - that wages only adjust gradually - is what meant, in The General Theory, that generalized unemployment could emerge.

Marshallian analysis seems - on the face of things - very straightforward. As a result, the Marshallian tradition was very powerful. It is no surprise that Keynes had such difficulty while serving on the Macmillan Committee. He had not yet understood why cutting wages would not, by itself, reduce unemployment.

To understand how unemployment can emerge, Keynes had to understand that macroeconomics is about more than just putting together microeconomic pieces. He had to understand that macroeconomics is about how markets interact with each other. Unemployment depends on the demand for goods. An excess of savings can cause a reduction in the demand for goods because of the way in which the interest rate is determined in the money market. And prices do not adjust to ensure that everything which is produced is purchased, but instead depend on the gradually adjusting level of wages which is determined in the labor market. These ideas about the interdependence between markets were set out by Keynes in his General Theory, and were then formalized by Hicks in his IS-LM system.

These ideas were necessary when Keynes turned to the second great question on which he was to focus for the rest of his life: how can countries at different levels of income and in different states of economic development interact with each other in economic harmony? But they were not sufficient. The General Theory did not deal with this second great question. Nevertheless it was important to do so. How should an economy like Britain in 1930 deal with rising unemployment when the economy was at the same time insufficiently competitive internationally? Keynes advocated an increase in public expenditure to the Macmillan Committee as a way of reducing this unemployment. But that would only make the international position worse. Something else must be done if that problem was to be dealt with, along with ensuring that unemployment was dealt with. 
Keynes had already begun to analyse this issue in his Treatise on Money, which was published in the same year that he appeared at the Macmillan Committee. The setting in the Treatise was not that of a closed economy (as in The General Theory) but instead the international system of the kind which Keynes described and analysed at the Macmillan Committee. Although the Treatise assumed full employment and was not applicable to Britain in the twentieth century, it contained a discussion of the need for both national monetary autonomy in the face of difficulties facing individual countries and a uniform international monetary standard that would stabilize the global price level and economy. The Treatise therefore provided Keynes with a way to proceed during the Second World War to formulate postwar plans for the international economy. But he needed to adapt this international framework to incorporate the findings of The General Theory.

\section{BEYOND THE GENERAL THEORY: KEYNES'S VISION FOR THE GLOBAL ECONOMY}

Keynes's first step was contained in a plan he put forward for a new postwar international monetary system in late 1941 that was designed to make such global full employment possible with the aid of what he called a 'Clearing Union.' His plan drew on the theoretical arguments in The General Theory, and also on the harsh practical example provided by Britain's return to the gold standard in 1925. He was concerned that a shortage of global lending to countries in balance-of-payments difficulty might trigger global malfunction in the form of a global recession. Keynes feared a series of currency crises like those of 1931 - a fear which many displayed in 2012 in the face of the difficulties of borrowing experienced by many European countries.

Keynes wanted a global monetary system in which international money would be sufficiently accommodating. His global Clearing Union was to be something like the clearing system within a national banking process that would meet global liquidity needs without any international risk and without any restraint. He wanted this to happen at a low level of global interest rates, and this was to prove a stumbling block in his negotiations with Harry Dexter White of the United States Treasury between 1942 and 1944.

Keynes believed that a gold-standard kind of mechanism could be both too expansionary as well as too contractionary. His reasons for this appear very modern. The European Monetary Union has features like those that concerned Keynes because separate countries have fixed exchange rates between them in the manner of the gold standard. Not only has this system forced countries in the European periphery to have excessively contractionary policies since the onset of the European crisis, but it has also meant that policies in these countries were excessively expansionary during the period before the crisis in the way Keynes thought was possible.

The need for something different from the gold standard was discussed in much detail with Harry Dexter White and others from the United States. Keynes had argued since the 1920s that the gold standard was broken, and he now understood more clearly why this was so. He had claimed in The General Theory that the wage and price adjustments do not work well; at the Macmillan Committee he had argued that these adjustments do not work fast enough or well enough to accomplish what we call the expenditure-switching component of the balance-of-payments adjustment process. Keynes reiterated that the attempt to rely on them had resulted in conflict and chaos in the interwar period. 
Keynes went on to argue that the first, short-run, component of the gold standard mechanism is likely to be destabilizing. Countries suffering external shocks and experiencing a spreading recession would be likely to come under political pressure to suspend membership of the gold standard. Capital holders would take fright at this possibility and capital would thus tend to flee those countries which experience negative external shocks, rather than cushion the adjustment of such countries to these shocks. Keynes was already beginning to produce ideas about self-fulfilling speculative attacks and financial crises, and there are parallels with what is happening in Europe today.

Keynes and Britain then ran up against a sting in the tail of Lend-Lease - the wartime finance which Roosevelt had provided for Britain at the end of 1940. Article VII of Lend-Lease stipulated that the United States would have the right to determine the institutional structure of the postwar world in return for donating resources to Britain through Lend-Lease. In effect, it was proposed that Lend-Lease would give the United States complete control over the form of the United Kingdom's long-run rehabilitation. The United States would be able to determine the conditions under which Britain could recover the export markets which it had abandoned during the war.

Keynes understood that, as the war against Germany was inescapable, there was no way to escape from the sting contained in Lend-Lease. Nevertheless he gradually realized that there was a way out of the impossible contradiction into which the United States was pushing his country. This escape route required him to remake the whole world. Suppose that free trade (including the absence of general balance-of-trade restrictions against the United States and the unwinding of more specific imperial preference) were to be imposed on Britain along with open international finance. The position of Britain might be maintained if trade were free and international finance were managed on a global basis. Could a multilateral world of global free trade and managed international finance really be made to work, to replace the imperial system of the late nineteenth century? Could Britain earn an important and prosperous place in such a brave new world?

One day in 1944, in a tedious meeting at the Board of Trade, Keynes sketched a plan that answered these questions on the back of an envelope. He passed it to James Meade and said, 'At last, I am convinced' (quoted in Vines 2008). Keynes listed four goals of international economic policies down the left side of his sketch. The first two goals were short-term in nature; the last two were long-term. There was a policy instrument for each goal since four instruments were needed to achieve four goals, and there were separate organizations to operate these instruments. The first organization, concerned with domestic balance, was national; all the others were international.

The first goal was full employment. This was national, representing balance within each country. The aim was to have full employment without inflation, a condition we call internal balance. As the goal was national, the organizations to make policies to achieve the goal were national as well. The United States Full Employment Act of 1946, revised and expanded in the Humphrey-Hawkins Full Employment Act of 1978, enjoined the United States government to reach this goal.

The second goal was adjustment of the balance of payments. This, and the goals that followed, were international. The institutions to accomplish these goals had to be international as a result. Keynes anticipated a set of pegged rates that could be adjusted from time to time as needed. This became the basis of the Bretton Woods System after the war ended. The International Monetary Fund was the institution that would help nations adjust their exchange rates, advise them when adjustments were needed, and deal with crises that could occur if adjustments were delayed. 
The IMF, as it is known around the world, has grown to be a central monitor and sometimes actor in the world economy.

Keynes's third goal was the promotion of international trade. He hoped that tariffs would be reduced after the war to promote trade. Since the Americans were determined to dismantle the British trading system of the 1930s, Keynes hoped that free trade around the world would provide opportunities for countries like Britain to prosper. An international trade organization, now known as the World Trade Organization, pursues this goal in a series of international meetings that only sometimes enhance the goal of free trade.

Finally, Keynes returned to his concerns in The Economic Consequences of the Peace and saw the need to promote economic development. He had maintained his interest in this goal for a quarter of a century, and he wanted to establish an organization to promote it through international lending. Accordingly, he proposed that a World Bank would complement the IMF among the new institutions. The IMF would deal with short-run problems of financial adjustment, while the World Bank would provide long-term lending to support the longer-run goals of economic growth. He hoped that the prosperity that came from international growth and specialization would enable the European conditions before the First World War that he had described in The Economic Consequences to spread throughout the world.

How did Keynes get to this conclusion? In the decade or so since he was writing The General Theory, he had incorporated macroeconomic thinking into his framework. No longer did he struggle against Marshall; instead he firmly asserted that several markets needed to be in equilibrium for the economy to be in equilibrium. Building on Hicks's IS-LM system, but well before Samuelson's neoclassical synthesis, Keynes had become comfortable with the new field of economics he had created. His objectives were multi-dimensional. Having understood what he was doing, Keynes came to see that for a single economy one needed to consider not just the market for domestic goods, and the need to achieve full employment of labor (that is, what we may call internal balance), but one also needed to include the international trading market (the balance of payments) and the need to achieve what we may call external balance (that is, a satisfactory balance-of-payments position).

Keynes then went on to increase the number of countries to more than one. He saw that with two countries, one would want to achieve internal balance in both of the countries and also to achieve external balance between them (that is, a satisfactory balance-of-payments position between them). It would take economists many years to figure out how to do this analytically, but Keynes leapt to this next step without effort. In developing his new model, Keynes continued his procedures from the early 1930s, sending messages to his colleagues and students, as he had done in the Circus, and letting them work out the details. The big difference was that he now understood more thoroughly what he was doing and could send more complete messages.

This model of international macroeconomics was not written down until 1951, when James Meade published it in The Balance of Payments for which he was awarded the Nobel Prize. Meade was a key player in Keynes's invention of the model, and he described his work as one that 'does not claim to make any significant contribution of original work in the fundamentals of pure economic analysis' and has an 'indebtedness to the ideas of Lord Keynes too obvious to need any emphasis' (Meade 1951, p. ix). This model became easy to grasp as a result of the Swan diagram, but it only came into popular use in the middle 1980s, since when it has become a core part of international macroeconomics. 
The mature Keynes thus continued the international interests of the younger Keynes, and gradually turned his earlier insights into a tractable macroeconomic model. In doing this he returned to his earlier concerns about the world economy, after his important contributions to our understanding of the domestic economy. That improved analysis of the domestic economy was a necessary step, and it led to a sea-change in our understanding. But it was only one part of the much larger Keynesian legacy. Keynes's achievement was to provide us with a much expanded understanding of the workings of the global economy.

\section{THE ESSENTIAL RELEVANCE OF KEYNES FOR CONTEMPORARY EUROPE}

Keynes's tractable macroeconomic model - and his understanding of the workings of the global economy - can help us understand what has gone so badly wrong in Europe recently. The European Monetary Union was established with too little understanding of the things that we have been discussing in this paper. Two fundamental things went badly wrong during the first decade of the euro's existence. Financial liberalization was badly managed; there was undisciplined over-lending to the GIIPS countries (Greece, Italy, Ireland, Portugal, and Spain), by banks within those countries, by northern European banks, and by global banks. As a consequence, these countries over-borrowed, leading to excessive inflation, and wages and prices in the GIIPS countries moved out of line with those in Germany by up to 30 or 40 percent. This is a competitiveness problem; relative unit labor costs became too high.

The newly created European institutions - both the European Central Bank in Frankfurt and the European Commission in Brussels - allowed a too-rapid expansion of demand to happen in these countries. Apart from Greece, this problem was not a too-rapid expansion of public debt. Instead there was a too-rapid increase in private bank-lending to these countries. These countries did exactly what Keynes saw as being possible on a gold standard. There was much more rapid expansion in these countries than in the north of Europe, and they become dangerously uncompetitive.

Suddenly, at the end of 2008, the global financial crisis struck the world. In Europe, as everywhere, there was a massive downturn in aggregate demand. But by early 2010 it became very clear that the uncompetitive GIIPS countries had become particularly vulnerable because they had over-borrowed so extensively. In particular, these countries had become fiscally vulnerable. The collapse in global output hit fiscal revenues everywhere, but in the uncompetitive GIIPS countries it became clear that fiscal debts might never be repaid. As a result, Europe faced a number of sovereign debt crises. Previously such crises were only found in emerging market economies: Latin America (1981), East Asia (1997), Russia (1998), and Argentina (2001). Suddenly, such crises came to Europe.

The eurozone survived that crisis. We were all relieved; there was general optimism by the end of 2013. Mario Draghi, the President of the European Central Bank (ECB), had announced in the summer of 2012 that the ECB would do 'whatever it takes.' We came to believe, for a while, that Draghi spoke the truth. But that optimism was an intermezzo. Now we are all back in the Opera House again, for the final act in the eurozone drama.

Rescue from catastrophe is still possible. But it will require three large changes to European policymaking. These are precisely the kinds of policies that Keynes would be urging upon us if he were with us today. 
First, the countries in Southern Europe need to regain their competitiveness. This is difficult for countries within the European Monetary Union, just as it was difficult for Britain within the gold standard. Keynes understood this problem very clearly in 1930. As we have discussed, he understood that it is very difficult for a country to do this if it needs to cut its level of wages and prices. The difficulty is now apparent in Europe. In the face of this difficulty, much more inflation in Germany is required. German inflation needs to be two or three percent above Europe's two percent inflation target for four or five years. Given Germany's resistance to inflation, it is very hard to imagine this happening.

Second, there needs to be much more fiscal expansion in Germany, two or three percent of GDP for four or five years, coupled with a relaxation in austerity in the south of Europe (that is, in the GIIPS countries). This is precisely the kind of fiscal expansion that Keynes advocated for Britain when he spoke at the Macmillan Committee. Achieving a relaxation of the fiscal position in Germany is a large demand, likely to be resisted in a country that is preoccupied with the fiscal costs of supporting an ageing population (and which has memories of the catastrophic hyperinflation of the 1920s). So preoccupied is Germany with this issue that the country has passed a constitutional amendment forbidding the kind of fiscal relaxation that is fundamentally necessary.

Third, there will need to be forgiveness of much of the debt of southern European sovereigns. This need corresponds to the need identified by Keynes in his 1919 Economic Consequences of the Peace. The way in which such debt relief is possible, and necessary, is made clear by even a brief study of the Latin American debt crisis of the 1980s. At the time, the major United States banks stood against such a move. This stand enabled them to rebuild their balance sheets, over a period of some years, at the expense of Latin American nations, in much the same way as banks are now doing in Europe. Debt relief was inevitable then in Latin America, and it is inevitable in Europe now. But Germany stands resolutely against such debt forgiveness for Greece and for other southern European countries as well. There is a heavy irony in this, since half of German debt was written off in 1953 in a way that made possible the postwar economic miracle in Germany.

This history appears more relevant to current circumstances outside Germany than inside. There are two explanations why this unhelpful view has been adopted by Germany. In the first view, Germany understands Keynesian analysis and realizes that the latest 'extend and pretend' agreement with Greece will depress the Greek economy further by extending austerity and make it ever harder to pay Greek debt. Germany wants this outcome to keep the value of the euro low and allow Germany to continue its aggressive export strategy. In addition, Germany wants this outcome because forgiving Greek debt would create a queue of other nations seeking debt forgiveness: Portugal, then Spain, and - worst of all - Italy. Germany regards Greek suffering, and the suffering of other peripheral European countries, as a small cost to pay for the continuance of German prosperity.

In the second view, Germans ignore not only their history but also the abundant evidence that austerity depresses economic activity - exactly as Keynes argued. Ever since 2008, the evidence for this Keynesian proposition has been abundant throughout Europe. But Germans are ordoliberals and cannot absorb English theorizing like Keynesian economics.

The second view seems more depressing than the first. In holding this view, Germans now are acting like the audience to which Keynes lectured at the meetings of the Macmillan Committee. Those people could not relinquish their attachment to the gold standard; many Germans now will not let go of their attachment to ordoliberalism. 
More details of many of the arguments in this paper may be found in Peter Temin and David Vines's The Leaderless Economy (Princeton University Press, 2013) and Keynes: Useful Economics for the World Economy (MIT Press, 2014).

\section{REFERENCES}

Keynes, J.M. (1919), The Economic Consequences of the Peace. The Collected Writings of John Maynard Keynes, vol. II, Cambridge, UK: Cambridge University Press.

Keynes, J.M. (1936), The General Theory of Employment, Interest and Money, London: Macmillan.

Keynes, J.M. (1981), Activities 1929-1931: Rethinking Employment and Unemployment Policy. The Collected Writings of John Maynard Keynes, vol. XX, Cambridge, UK: Cambridge University Press.

Meade, J.E. (1951), The Theory of International Economic Policy, vol. 1: The Balance of Payments, London and New York: Oxford University Press.

Norman, M. (1931), H.M. Treasury, Report of the Committee on Finance and Industry (Macmillan Committee), Cmd 2897, Minutes of Evidence, 2 vols.

Vines, David (2008), 'Meade, J. E.,' in Stephen Durlauf and Lawrence Blume (eds), New Palgrave Dictionary of Economics, 2nd edn, vol. 5, London: Macmillan, pp. 485-503. 